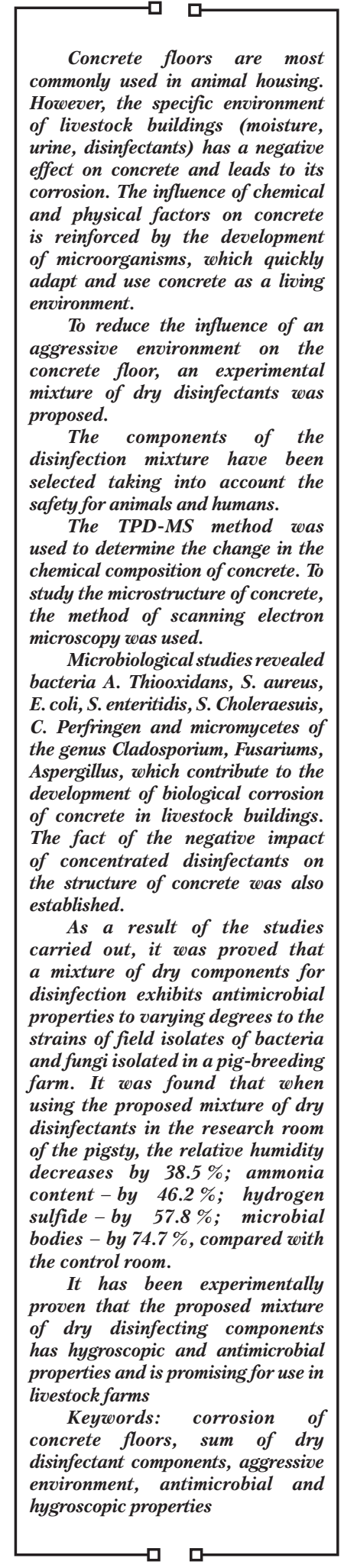

UDC 614.48:631.223

DOI: $10.15587 / 1729-4061.2021 .236977$

\section{DEVELOPMENT OF A METHOD OF PROTECTION OF CONCRETE FLOORS OF ANIMAL BUILDINGS FROM CORROSION AT THE EXPENSE OF USING DRY DISINFECTANTS}

\author{
Oksana Shkromada \\ Corresponding author \\ Doctor of Veterinary Sciences, Professor \\ Department of Obstetrics and Surgery** \\ E-mail: oshkromada@gmail.com \\ Tatiana Fotina \\ Doctor of Veterinary Sciences, Professor* \\ Roman Petrov \\ Doctor of Veterinary Sciences, Professor
}

Department of Virusology, Patanatomy and Bird Diseases Named after professor I. I. Panicar**

Li u d m y la $\mathbf{N a g o r n a}$

Doctor of Veterinary Sciences, Professor Department of Veterinary Examination, Microbiology, Zoohygiene and Safety and Quality of Livestock Products**

O lexandr Bordun

$\mathrm{PhD}$, Senior Researcher

Laboratory of Animal Husbandry and Fodder Production Institute of Agriculture of the Northeast of the National Academy of Agrarian Sciences of Ukraine Zelena str., 1, Sad vil., Sumy dist., Sumy reg., Ukraine, 42343 Marina Barun

$\mathrm{PhD}$, Associate Professor Department of Ecology Kharkiv National Automobile and Highway University Yaroslava Mudroho str., 25, Kharkiv, Ukraine, 61002

O I e n B a be n ko $\mathrm{PhD}$

Department of Chemistry and Methods of Teaching Chemistry Sumy State Pedagogical University named after A.S. Makarenko

Romenska str., 87, Sumy, Ukraine, 40002

Maks y $\mathrm{Karpulenko}$

$\mathrm{PhD}$

Department of Epizootology State Scientific and Research Institute of Laboratory Diagnostics and Veterinary and Sanitary Expertise Donetska str., 30, Kyiv, Ukraine, 03151

Taras Tsarenko

$\mathrm{PhD}$, Associate Professor Department of Epizootology and Infectious Diseases Bila Tserkva National Agrarian University Soborna sq., 8/1, Bila Tserkva, Ukraine, 09117

Vyacheslav solomon $\mathrm{PhD}$, Associate Professor Department of Veterinary Hygiene named after Professor A.K. Skorokhodko National University of Life and Environmental Sciences of Ukraine Heroiv Oborony str., 15, Kyiv, Ukraine, 03041 *Department of Veterinary Examination, Microbiology, Zoohygiene and Safety and Quality of Livestock Products** **Sumy National Agrarian University Herasyma Kondratieva str., 160, Sumy, Ukraine, 40021

\section{Introduction}

The animal breeding room is made of concrete. Despite the reliability of the building material, there are certain fac- tors of its destruction, which lead to a decrease in the service life. The production of concrete structures remains popular and is constantly being improved. It remains to solve a number of problems with chemical and biological corrosion of 
concrete. At the beginning of research it is important to find out the cause of corrosion. Namely, to investigate chemical and biological factors and determine the critical period of destruction for concrete structures.

When operating livestock buildings, conditions are created for the growth of micro-fungi and bacteria. At the beginning of the formation of a favorable environment, autotrophic microorganisms begin the process of assimilation. Further, specific bacteria and fungi use concrete as a medium for existence. The dissimilation process starts very quickly, due to the presence of a sufficient amount of moisture and a positive temperature. Also microorganisms are highly resistant to chemical disinfectants. In addition, with the constant use of one disinfectant, highly resistant strains of microorganisms arise.

It should be noted that chemical disinfectants are quite aggressive compounds that cause destruction of the concrete surface. Disinfectants are used in a liquid, dry and aerosol state. The most commonly used compounds are chlorine, oxidizing agents, phenols, aldehydes, acids and alkalis.

In addition, biogenic excretions from animals, such as urine and faeces, act on concrete floors. Also, the sewage system for manure removal suffers from specific biological corrosion. Thus, it has been established that chemical and biological corrosion affects concrete floors in livestock buildings.

In livestock buildings, to increase the service life of concrete floors, forced ventilation and mechanical cleaning of manure are used. They also carry out current repairs to eliminate cracks in concrete, arrangement of channels for the drainage of fluid and pus. When keeping animals on the floor, let's use a deep bedding of straw or sawdust. However, all these measures do not generally solve the problem of concrete corrosion.

In order to reduce the corrosive effect of high humidity, biogenic secretions, microorganisms and chemically aggressive compounds on concrete floors, it is proposed to use a mixture of dry disinfectants based on (\%): chloramine -0.2 ; thymol -0.1 ; copper sulfate -2.0 ; iron sulfate -1.0 ; calcium sulfate dihydrate -45.0 ; zeolite -42.0 ; kaolin -9.6 .

The disinfection mixture has a neutral $\mathrm{pH}$, while destroying $99 \%$ of microorganisms due to the synergistic effect of the components. In addition, the disinfectant reduces indoor moisture and the concentration of urine on the concrete surface. The relevance of such research lies in the development and introduction into production of a mixture of dry disinfecting synergistically selected components to prevent the occurrence of biological and chemical corrosion of concrete floors in livestock buildings.

\section{Literature review and problem statement}

Concrete structures are subject to various types of corrosion in aggressive environments. Excessive moisture and autotrophic microorganisms that quickly colonize building materials lead to a worsening of the situation. Concrete structures in sewer systems, marine construction, underground construction and other humid environments are susceptible to microbial attachment, colonization and ultimately deterioration. Researchers, through careful selection and research, have found that certain additives, including inorganic and organic antimicrobial agents, can confer remarkable antimicrobial properties in concrete. However, the experiment does not give recommendations as to the possibilities of destroying microorganisms on the surface of concrete in the rooms are exploited [1,2].

The solution to this problem can be the use of a disinfectant, which in low concentrations can destroy a wide range of microorganisms. The disinfectant sodium chloramine tosylchloramide (CAS 127-65-1, EINECS 204-854-7) contains $25 \%$ active chlorine. A universal powder disinfectant is based on active chlorine.

Recommended for disinfection in medical, agricultural, industrial, food and other institutions where there is a risk of a large biological and infectious load.

The disadvantage of this product is its corrosiveness in high concentrations. However, the use of chloramine in low concentrations (e. g. $0.2 \%$ ) does not show a destructive effect on the concrete surface. In addition, chloramine has sporicidal activity and hygroscopic properties [3].

There is a common problem with the walls of reinforced concrete structures in sewer tunnels, especially after a long period of use. Corrosion is caused by biological sulfuric acid produced by thionic bacteria. Bacteria of the genus Thiobacillus under anaerobic conditions convert hydrogen sulfide gas into corrosive sulfuric acid. The work used nanomaterials to protect concrete from corrosion [4]. The proposed method of antimicrobial corrosion has insufficient experience in testing its durability in aggressive production environments.

In livestock buildings, there is a problem of the influence of an aggressive environment on building structures, especially the floor. Pus and urine constantly accumulate on the floor, which are difficult to remove even with careful mechanical cleaning. In addition, there is a daily use of disinfectants in animal husbandry. Disinfectants are most often represented by concentrated alkalis or acids, which lead to carbonization of the surface layer of concrete. To solve these problems, researchers in the work proposed on the basis of nanoparticles of titanium dioxide (nano $\mathrm{TiO}_{2}$ ), finely dispersed titanium dioxide in anatase crystalline form (anatase $\mathrm{TiO}_{2}$ ), surfactants (alkyl trimethylamine chloride), which makes it possible to increase the resistance of concrete under aggressive operating conditions. However, the experience does not consider the issue of concrete protection during long-term operation [5].

Kaolin can be proposed as a finely dispersed component for protecting concrete floors that have been in operation for a long time. Kaolin is a naturally occurring mineral that contains aluminum and silicon oxide. The properties of kaolin include adsorption and ion exchange activity. Studies have shown [6] that kaolin is an excellent sorbent for bacteria. In addition, kaolin does not affect concrete structures and is safe for animals, even if it enters the body with water [7].

Warehouses for storing liquid manure in pig or dairy farms represent a significant part of investments in agricultural infrastructure. It is important that these facilities work properly and that they do so throughout their lifecycle. However, concrete in outbuildings is exposed to high concentrations of hydrogen sulfide $\left(\mathrm{H}_{2} \mathrm{~S}\right)$ and sulphates, which leads to a deterioration in the condition of reinforced concrete. This leads to premature wear on the piers and floors. In some pig shops, a $50 \%$ loss in expected life has been reported [8].

Also, experiments carried out by the researchers proved that the cause of concrete corrosion in livestock buildings is micro-fungi of the genus Penicillium, Fusarium, Cladospo- 
rium, Aspergillus and bacteria Escherichia coli and Pseudomonas aeruginosa. When carrying out microscopic studies by immersing concrete samples on Mesopotamia agar, it was proved that an additive to concrete, which includes: yellow iron oxide pigment, water glass, copper sulfate and peracetic acid, have antimicrobial properties [9]. However, the problem is the limited life of antimicrobial properties.

All materials (wood, metal and concrete) used in the construction of outbuildings are at risk of corrosion. Metal and concrete structures are easily corroded by chemicals in manure products, organic and inorganic acids, which lead to the formation of iron and iron oxides and weight loss. Prolonged exposure of concrete structures to manure, agricultural runoff and other chemicals leads to hydration of the cement, the formation of calcite crystals, and the breakdown of the structure. In addition, poultry manure has been associated with a pronounced risk of corrosion compared to pig or cattle manure, possibly due to high concentrations of $\mathrm{H}_{2} \mathrm{~S}$ and $\mathrm{NH}_{3}$ and other corrosive agents [10]. Researchers have proposed the use of sulfate-resistant cement for concrete flooring in the construction of livestock farms. The issue of protecting the already existing structures of livestock buildings remained unsolved.

Also, the construction of agricultural structures from materials that provide optimal production against corrosion, such as ash and or impregnation of the concrete mixture with silica vapors does not fully guarantee the durability of concrete.

The use of thymol powder as an environmentally friendly disinfectant can solve the problem of the corrosive effect of microorganisms on building materials. Thymol (2-isopropyl-5-methylphenol) $-\mathrm{C}_{10} \mathrm{H}_{14} \mathrm{O}$, natural monoterpene phenol, isomer of carvacrol. Thymol was obtained from the essential oil of Thymus vulgaris. It is a crystalline substance that has a strong aromatic odor. Thymol exhibits antimicrobial properties, due to the destruction of membranes of bacteria and microsporidia, and organic biofilms on the surface of building materials [11].

Poultry disinfection programs use hydrated lime to provide more light intensity for the birds and improve the appearance of the farm. However, according to this study, hydrated lime was more effective than currently available disinfectants [12]. Unfortunately the use of slaked lime is possible for walls, but not practical for use on concrete floors. In addition, slaked lime does not solve the problem of moisture reduction in the room.

A way to overcome the increased humidity in the room can be the use of substances that have hygroscopic properties, such as zeolites. Zeolites are a group of minerals, hydrous aluminosilicates. The ability to absorb liquid in zeolites is related to their porous and channel structure. This type of microporous structure provides the zeolite with a large internal surface in relation to the external, which is associated with increased ability to exchange cations (which makes it a hydrophilic compound), is able to effectively adsorb polar molecules. Natural zeolites, which are mined in Ukraine in the Transcarpathian region, containing clinoptilolite. This type of zeolite has high thermal, mechanical and chemical resistance [13]. Natural zeolites act as a sorbent for inorganic and organic compounds. The disadvantage of zeolites is a certain size of cavities through which suction passes and large lobules cannot be absorbed [14, 15]. The advantage of natural zeolites over artificial ones is the ability to regenerate.
Also, the assessment of the effectiveness of disinfectants should not be limited to laboratory tests. Field tests should be used to assess the actual effect of disinfectants. In addition, it is important to consider that field samples can be used to identify bacteria and test the sensitivity of isolated microorganisms to disinfectants.

Studies conducted at the Helm State Hospital and Health Office, Algeria, proved that $52 \%$ of the vast majority of bacteria studied were susceptible to copper sulfate. The maximum bactericidal activity of copper sulfate was recorded against Proteus vulgaris and Staphylococcus aureus. However, strains resistant to copper sulfate (Escherichia coli, Staphylococcus saprophyticus) were isolated [16]. The experimental dry ingredient mixture includes several compounds for maximum antimicrobial spectrum.

The researchers conducted an experiment on a dairy farm in China. As a result of the research, it was found that the use of drinking water with the addition of calcium sulfate at $21{ }^{\circ} \mathrm{C}$ significantly suppressed the growth and reproduction of E. coli up to $10^{5} \mathrm{CFU} / \mathrm{ml}$ [17]. However, the exact mechanism by which calcium sulfate acts on bacteria has not been established. In addition, the question arises of the concentration of the disinfectant in the intestinal contents.

Summing up the work of the researchers, it can be noted that it is impossible to completely prevent the corrosion of agricultural buildings, but it can be reduced through the choice of materials and preventive measures.

One of the important factors in preventive measures is the choice of an effective disinfectant with the least corrosiveness to concrete.

The proposed mixture dry mixture for disinfection contains active ingredients (\%): chloramine -0.2 ; thymol -0.1 ; copper sulfate -2.0 ; iron sulfate -1.0 ; calcium sulfate dihydrate -45.0 ; zeolite -42.0 ; kaolin -9.6 .

When choosing components for a dry disinfectant mixture, we were guided by modern requirements for disinfectants. The main ones are considered safety when used in the presence of people and animals. A wide spectrum of bactericidal action is also important. In addition, hygroscopic properties and low corrosive effects on concrete structures were additionally taken into account.

So, the use of an experimental dry mix for disinfection is advisable to improve the corrosion and microbial resistance of concrete floors.

\section{The aim and objectives of research}

The aim of research is to develop and introduce a mixture of dry disinfecting synergistically selected components to enhance anti-corrosion resistance and extend the life of concrete floors in livestock buildings.

To achieve this aim, the following objectives were solved:

- to establish the reasons for the formation and the degree of chemical and biological corrosion of concrete floors in livestock buildings;

- to investigate the antimicrobial activity of the proposed mixture of dry components for disinfection relative to isolated strains of field isolates in livestock buildings;

- to determine the hygroscopic properties of the experimental mixture for disinfection when used on the surface of floors in livestock buildings. 


\section{Materials and methods of research}

\section{1. The object and conditions of research}

The studies were carried out in the laboratory of veterinary medicine of the Sumy National Agrarian University during 2020-2021 (Sumy, Ukraine).

Industrial research was carried out under the conditions of the State Enterprise for Research Economy of the Institute of Agriculture of the North-East of the National Academy of Agrarian Sciences of Ukraine p. Garden, Sumy region, Sumy region.

The research was carried out in a pigsty in a nursery workshop. The room was built in 1980. During this period, several cosmetic repairs were carried out. The animals are housed in a brick building with a concrete floor. Manure cleaning is done manually. Due to the high density of stocking of animals, it becomes necessary to carry out daily preventive disinfection. Therefore, the effectiveness of the disinfectant is of great importance.

Disinfection using an experimentally developed mixture of dry components was carried out after thorough mechanical and sanitary cleaning, by uniformly sprinkling the floor surface at a rate of $50-100 \mathrm{~g} / \mathrm{m}^{2}$.

\section{2. Technique for examining concrete samples using} TPD MS

To study the heat resistance of concrete, a thermoprogrammed mass spectrometry (TPD MS) unit was used. Concrete samples were obtained from the control room farm office and research - pigsty room (nursery workshop). The structures were built in one time 1980. Heating samples of concrete weighing 5-10 mg were conducted at the temperature 40 to $900{ }^{\circ} \mathrm{C}$. Simultaneously recorded using the mass spectrum of the mixture of gases and identified them by molecular weights $(\mathrm{m} / \mathrm{z})$ : 18 - water; 44 - carbon dioxide $\mathrm{CO}_{2}, 48$ - sulfur oxide $\mathrm{SO}$ [18].

\section{3. Technique of scanning electron microscopy}

The study of the microscopic structure of concrete was carried out by scanning electron microscopy on an REM 106 device (JSC SELMI, Sumy, Ukraine). The studies were carried out in a scanning electron microscope in the secondary electron mode in the range of electron-optical magnifications from 200 to 5000 times. Biofilms on concrete samples were

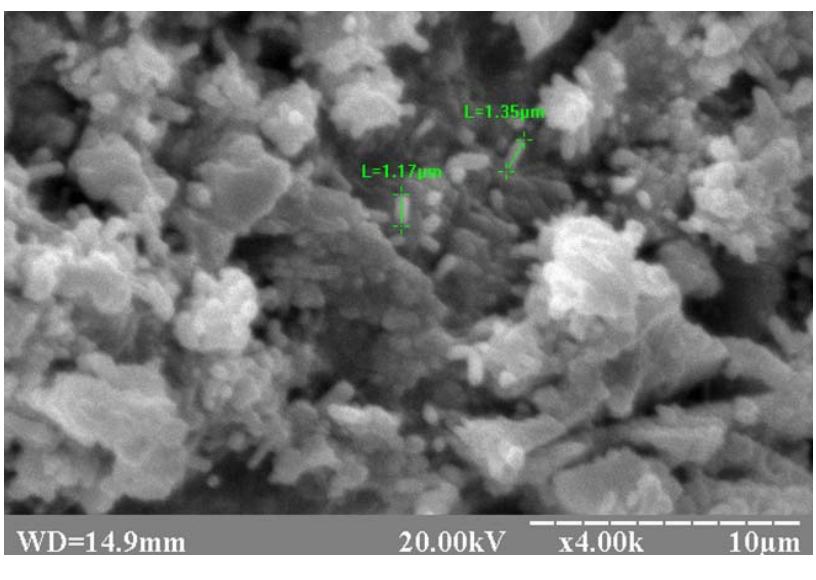

examined after fixation in $2.5 \%$ glutaraldehyde in $0.2 \mathrm{M}$ phosphate buffer solution. The deposition of samples to provide electrical conductivity was performed with silver [19].

4.4. Method for determining the microclimate in the pigsty room and conducting microbiological studies

Determination of the content of carbon dioxide, ammonia and hydrogen sulfide was carried out using a gas analyzer. The relative humidity of the air in the room was investigated with a static psychrometer by August, the bacterial pollution of the air - with the device of Yu. Krotov. Washes from the surface of the structures of livestock buildings (walls, floor) were taken in the pig breeding workshop. The bacteria were grown on elective media. The cultivation was carried out according to the species of the microorganism [20]. Microscopic fungi were cultivated in Petri dishes on Czapek-DOXA medium [21].

4. 5. Methods for determining the antimicrobial action of an experimental mixture of dry components for disinfection

The mixture for disinfection was poured into the wells in Petri dishes on MPA with isolated strains of microorganisms in pig breeding rooms. Cultivation of bacteria and fungi was carried out taking into account the cultural characteristics of microorganisms. After 48 days, the zones of inhibition of the growth of microorganisms around the wells with the disinfectant mixture were determined [22].

\section{Results of the study of concrete floors and the use of} an experimental dry mix for disinfection in a pigsty

5. 1. Results of determining the causes of corrosion of concrete floors in the pigsty room

Indoors, concrete is impregnated with fecal matter and urine, which contain a significant amount of natural carbonate $\mathrm{H}_{2} \mathrm{CO}_{3}$ and sulfuric $\mathrm{H}_{2} \mathrm{SO}_{4}$ acids. In addition, microorganisms and disinfectants constitute an aggressive environment that destroys concrete structures, especially floors. In connection with the prevailing specific conditions on the surface of concrete structures, a number of microorganisms were isolated (Table 1). However, the bacterial biofilm on the concrete floor surface was formed by Acidithiobacillus thiooxidans (Fig. 1, $a$ ) and Aspergillus fumigatus (Fig. 1, $b$ ).

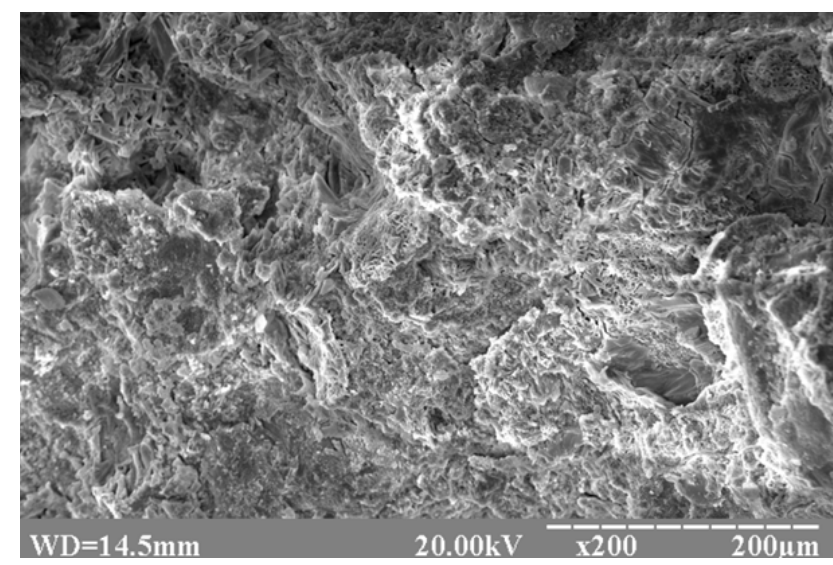

$b$

Fig. 1. Scanning electron microscopic image of a biofilm on concrete of microorganisms: $a$-Acidithiobacillus thiooxidans; $b-$ Aspergillus fumigatus 
The conducted studies of concrete floor samples by the TPD MS method confirm the presence of a change in the chemical composition of concrete under the influence of biological and chemical corrosion of livestock farms (Fig. 3).

It was experimentally established that on the graph the control sample, when heated to $580{ }^{\circ} \mathrm{C}$, has a clear peak with an intensity of 0.40 . The concrete floor sample obtained from the surface did not emit $\mathrm{CO}_{2}$ when heated. The result indicates the destruction of the surface layer of concrete (Fig. 2, $a, b$ ) and a change in the chemical composition of concrete. In addition, a concrete sample taken from a depth of $1 \mathrm{~cm}$ from the surface emits carbon dioxide with an intensity of 0.25 at a temperature of $500{ }^{\circ} \mathrm{C}$ and forms a peak. Thus, it can be assumed that the destruction of the concrete surface up to $1 \mathrm{~cm}$ during long-term operation of the rooms is caused by the influence of chemical factors (disinfectants and manure) and biological (waste products of bacteria and micromycetes).

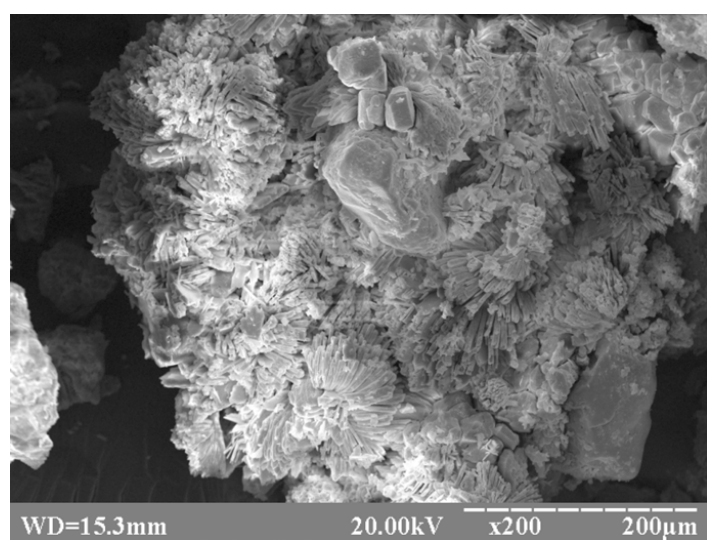

$a$

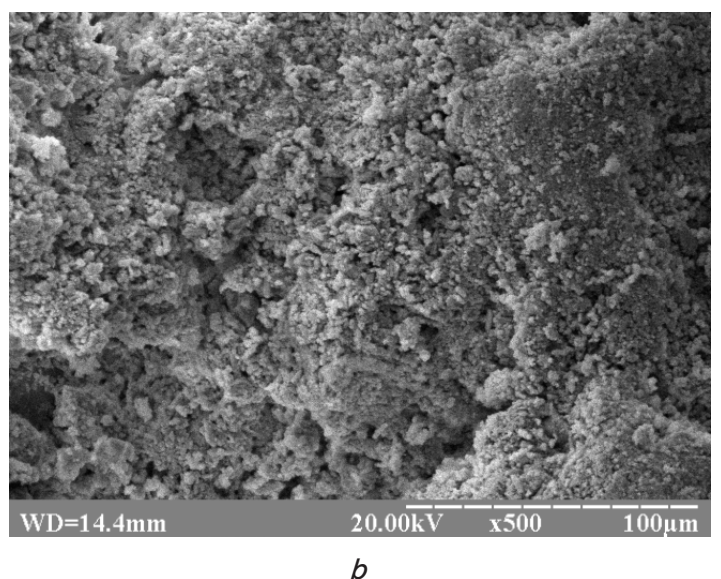

Fig. 2. Scanning electron microscopic image: $a$ - formation of calcites under the influence of micromycetes;

$b$ - destruction of the surface layer of concrete under the influence of chemical and biological corrosion

The absence of carbon dioxide in the concrete samples from the surface is associated with the growth of Aspergillus microscopic fungi (Fig. 1,b). Fungi bacteria use in the process of metabolism to synthesize organic acids that interact with $\mathrm{CO}_{2}$. As a result of the reaction, characteristic crystals of calcium citrate are formed (Fig. 2,a).

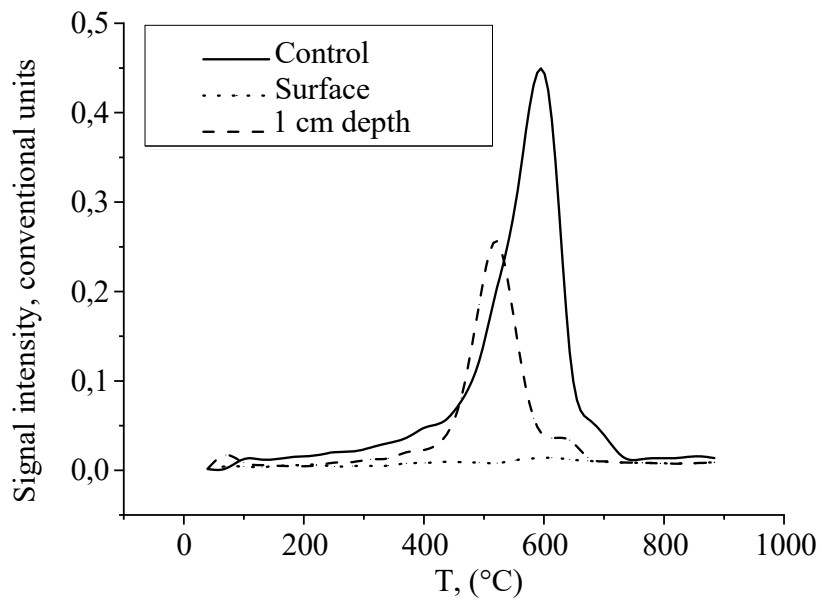

$a$
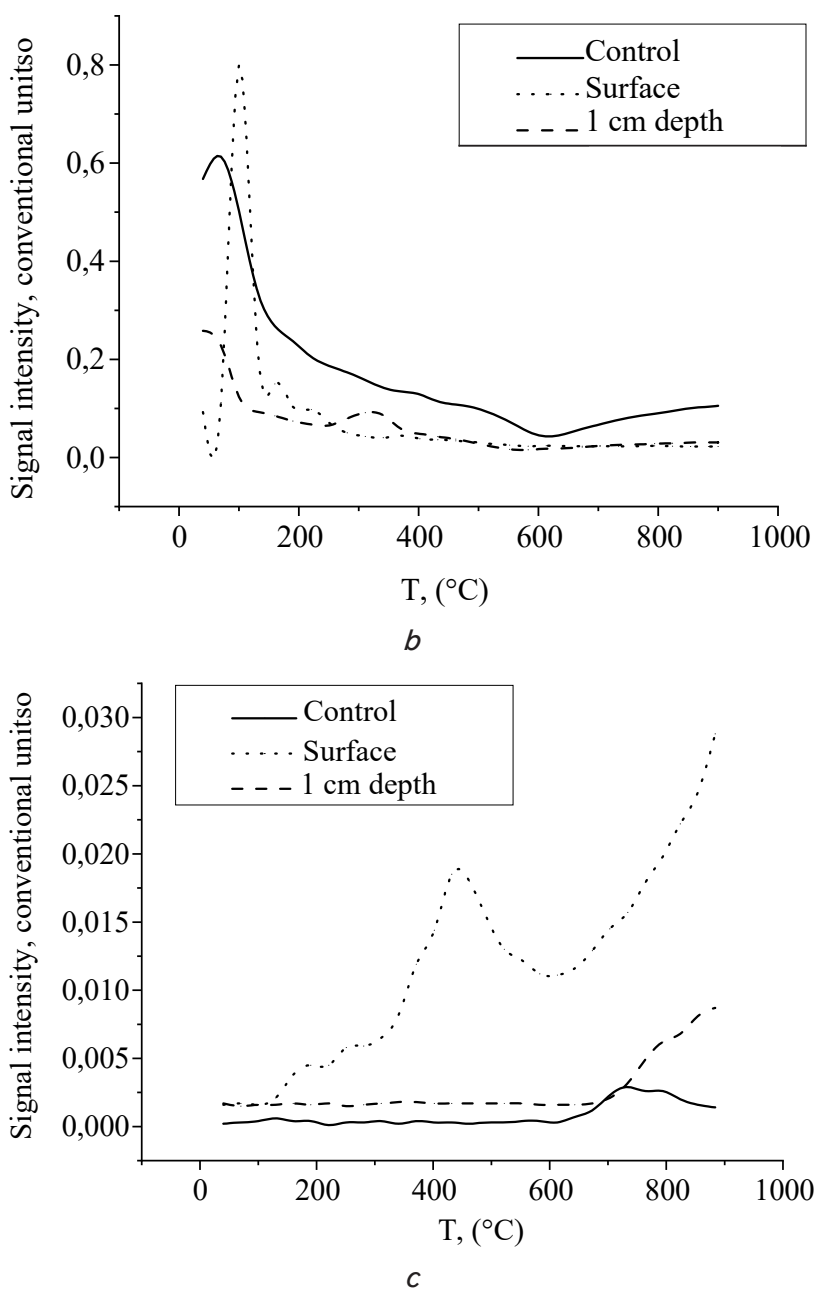

Fig. 3. Thermograms of release from concrete samples in the pigsty room: $a-\mathrm{CO}_{2}(\mathrm{~m} / \mathrm{z} 44) ; b-\mathrm{H}_{2} \mathrm{O}(\mathrm{m} / \mathrm{z} 18)$; $c-\mathrm{SO}(\mathrm{m} / \mathrm{z} 48)$

During heating of concrete specimens, the intensity and temperature of water release were also recorded (Fig. 3, b). As a result of the study, it was confirmed that at $100{ }^{\circ} \mathrm{C}$ with an intensity of $0.8, \mathrm{H}_{2} \mathrm{O}$ evaporated from the sample from the surface of the research room. This result was obtained due to the destruction of the surface and the constant presence of 
moisture. From the control sample and from a depth of $1 \mathrm{~cm}$, moisture evaporated for a long time at a temperature of 100 to $800{ }^{\circ} \mathrm{C}$ with low intensity. No clear peak was observed in the thermogram.

The samples from the control room and from the research room from a depth of $1 \mathrm{~cm}$ underwent less destruction and chemical destruction. This is indicated by the results of destruction obtained when these objects are heated for a long time, even at temperatures up to $800^{\circ} \mathrm{C}$. In addition, in a control concrete sample and a research one from a depth of $1 \mathrm{~cm}$ when heated, sulfur oxide is released (Fig. 3, c). However, in the samples from the surface, SO is released with an intensity of 0.02 at a temperature of $450{ }^{\circ} \mathrm{C}$ and forms a clear peak.

The change in the chemical composition of concrete on the surface of the pigsty floor confirms the presence of natural sulfuric acid, which is formed from the faeces of animals. Since this process is constant and long-term, thionic bacteria (Acidithiobacillus thiooxidans), which use sulfur for their metabolism, dissimilate concrete (Fig. 1). The destruction of the surface layer of concrete is clearly visible during electron microscopy (Fig. 4). With a strong destruction of concrete, the presence of cracks and lagoons can be seen with the naked eye.

As a result of the studies carried out, it was proved that the long-term operation of pig-breeding buildings leads to the destruction of the surface layer of the concrete floor as a result of exposure to chemical and microbial corrosion.

\subsection{Results of the study of the anti-} microbial activity of the experimental dry mixture for disinfection

In livestock buildings, a large number of microorganisms accumulate as a result of longterm operation. To determine the sensitivity of isolated strains of microorganisms isolated from the pig breeding rooms to the experimental dry mixture for disinfection, washings were carried out from the concrete surface. Then, using the disk method, an experiment was performed in Petri dishes to determine the size of the growth inhibition zone (Table 1).

Table 1

Sensitivity of microorganisms to the experimental dry mixture for disinfection $(\mathrm{M} \pm \mathrm{m})$

\begin{tabular}{|c|c|c|}
\hline Culture & number of colonies & growth retardation zone, $\mathrm{mm}$ \\
\hline S. aureus & $n=10$ & $6.22 \pm 0.12$ \\
\hline E. coli & $n=9$ & $10.12 \pm 0.15$ \\
\hline S. enteritidis & $n=8$ & $9.43 \pm 0.25$ \\
\hline S. choleraesuis & $n=8$ & $10.04 \pm 0.18$ \\
\hline C. perfringens & $n=10$ & $11.09 \pm 0.14$ \\
\hline A. thiooxidans & $n=9$ & $9.55 \pm 0.27$ \\
\hline Aspergillus & $n=12$ & $8.38 \pm 0.30$ \\
\hline Cladosporium & $n=10$ & $7.52 \pm 0.18$ \\
\hline Fusarium & $n=8$ & $5.65 \pm 0.22$ \\
\hline
\end{tabular}

Note: ${ }^{*}-p \leq 0.05$ compared to the lowest concentration.

According to the results of the experiment, it was found that the experimental mixture for disinfection exhibits antimicrobial properties against all isolated strains of field isolates of bacteria and fungi. The results obtained provide the basis for further testing it in production conditions.

\section{3. Results of the study of the microclimate in the} room for keeping pigs

Determination of microclimate parameters was carried out in the piglet rearing workshop. This room was chosen due to the high stocking density of 10-12 piglets per pen. In the control room, disinfection was carried out with $2 \%$ sodium hydroxide; in the research room, a dry mixture for disinfection of $50-100 \mathrm{~g} / \mathrm{m}^{2}$ was used (Table 2).

Table 2

Parameters of the microclimate in the pigsty when using an experimental dry mixture for disinfection, ( $M \pm m, n=10)$

\begin{tabular}{|c|c|c|c|c|}
\hline \multirow{2}{*}{ Indicators } & \multicolumn{2}{|c|}{ Control room } & \multicolumn{2}{c|}{ Experimental room } \\
\cline { 2 - 5 } & $\begin{array}{c}\text { immediately af- } \\
\text { ter disinfection }\end{array}$ & after 3 days & $\begin{array}{c}\text { immediately af- } \\
\text { ter disinfection }\end{array}$ & after 3 days \\
\hline$t,{ }^{\circ} \mathrm{C}$ & $18.65 \pm 0.23$ & $18.12 \pm 0.30$ & $18.15 \pm 0.37$ & $18.33 \pm 0.22$ \\
\hline $\begin{array}{c}\text { Relative humid- } \\
\text { ity, \% }\end{array}$ & $72.53 \pm 0.12$ & $70.28 \pm 0.16$ & $72.30 \pm 0.32$ & $43.20 \pm 0.21^{*}$ \\
\hline $\mathrm{CO} 2, \%$ & $0.14 \pm 0.03$ & $0.16 \pm 0.02$ & $0.15 \pm 0.02$ & $0.15 \pm 0.04$ \\
\hline $\begin{array}{c}\text { ammonia } \\
\left(\mathrm{NH}_{3}\right), \mathrm{mg} / \mathrm{m}^{3}\end{array}$ & $19.24 \pm 1.10$ & $19.45 \pm 1.12$ & $19.34 \pm 1.09$ & $10.35 \pm 1.22^{*}$ \\
\hline $\begin{array}{c}\text { hydrogen sulfide, } \\
\left(\mathrm{H}_{2} \mathrm{~S}\right) \mathrm{mg} / \mathrm{m}^{3}\end{array}$ & $11.20 \pm 0.20$ & $12.50 \pm 1.15$ & $11.37 \pm 1.23$ & $5.27 \pm 1.18^{*}$ \\
\hline $\begin{array}{c}\text { Total microbial } \\
\text { contamination, } \\
\text { thousand CFU } / \mathrm{m}^{3}\end{array}$ & 0 & $100.3 \pm 5.23$ & 0 & $25.3 \pm 3.42^{*}$ \\
\hline
\end{tabular}

Note: ${ }^{*}-p \leq 0.05$ compared to the control room

As a result of the experiment, it was found that the temperature index and the concentration of carbon dioxide in the air of the premises for keeping pigs were the same. The relative humidity in the research room on the third day of the experiment was $38.5 \%$ less than in the control room. Gases such as ammonia and hydrogen sulfide are part of the natural excreta of animals (urine and flare masses), therefore their concentration depends on the number of animals in the house and the rate of manure removal. In addition, a concrete floor will absorb enough moisture and urine like a sponge if it is not protected by disinfectants or bedding.

The use of the experimental dry mixture for disinfection in the research room on the third day of the experiment reduced the concentration of ammonia by $46.2 \%$ and hydrogen sulfide by $57.8 \%$, compared to the control. Generally, microbial contamination in a room is influenced by the number of animals, ventilation and sanitary conditions. In the research and control rooms, the conditions for the animals were identical. The only difference was in the disinfectant used.

According to the results of the study, a decrease in the number of microbial bodies in the research room was recorded by $74.7 \%$, compared to the control room.

It was established according to the results of the experiment that the proposed dry mixture for disinfection reduces moisture in the room, microbial contamination and the concentration of gases: ammonia and hydrogen sulfide. 


\section{Discussion of the results of the study of biochemical corrosion of concrete}

According to the results of the studies, the reasons for the emergence of an aggressive environment in the pigsty room were established. In the study of the microclimate in the pig rearing workshop, an increased humidity by $38.5 \%$, ammonia - by $46.2 \%$ and hydrogen sulfide - by $57.8 \%$ ( Table 2) in the control room was revealed. High humidity and optimal temperature create favorable conditions for the growth and development of microorganisms. In the pigsty, groups of bacteria and fungi of heterotrophs were identified that do not show great aggression to concrete: $S$. aureus, E. coli, S. enteritidis, S. Choleraesuis, C. Perfringen (Table 1) [21].

An undesirable corrosive effect occurs in the presence of high concentrations of $\mathrm{H}_{2} \mathrm{~S}$ and $\mathrm{NH}_{3}$, which create conditions for the development of thionic bacteria A. thiooxidans (Table 2). Microorganisms create a biofilm on the surface of the concrete floor (Fig. 1, $a$ ). In addition, A. Thiooxidans [22] in the process of metabolism after desimilation of concrete destroy its structure (Fig. 2,a), changing its chemical composition. In the samples, SO is released from the surface with an intensity of 0.02 at a temperature of $450{ }^{\circ} \mathrm{C}$ (Fig. 3, $c$ ).

Also, micromycetes of the genus Cladosporium, Fusariums, Aspergillus were isolated from the concrete surface of the pigsty premises (Fig. 1, $b$ ), which are capable of colonizing concrete and leading to destruction. Also, studies have proven that micromycetes use carbonate compounds in concrete in the process of its assimilation [23]. As a result of the reaction, characteristic crystals of calcium citrate are formed (Fig. 1, $b$ ). The thermogram (Fig. 3,a) shows the absence of $\mathrm{CO}_{2}$ emission from the concrete floor sample obtained from the surface.

Long-term use of concentrated disinfectants aggressively act on concrete, such as hydrochloric acid, formalin, hydrated lime, soda ash [24] and cause its corrosion. The conducted research has established the effectiveness of using an experimental dry mixture for disinfection in order to protect the surface layer of concrete from the destructive effects of moisture, fecal matter (Table 2) and microorganisms (Table 1). In addition, organic acids, ammonia, sulfates contained in natural excreta of animals increase the rate of swelling of concrete, accelerate the process of dissolution and softening of concrete structures, especially floors [25].

The hygroscopic effect of the experimental dry mixture for disinfection is due to the presence of zeolites in its composition, and the antimicrobial action is due to a complex of chemical components (chloramine; thymol; copper ferrous sulfate calcium sulfate dihydrate; kaolin). All components of the experimental dry mix for disinfection are inactive in dry form. Upon contact with bacteria and moisture, the process of destruction of microbial cells and organic biofilms is triggered. As noted earlier, all the components of the experimental dry mixture for disinfection have a different spectrum of antimicrobial activity and, when combined, a synergistic effect arises.

On the pig farm, specific conditions were investigated and analyzed, namely the microclimate of the premises, the composition of microorganisms and the disinfectants used. The study cannot be considered absolutely correct due to the limitations of the research material, since on other farms the service life of the premises, the conditions for keeping animals, microflora and disinfectants may differ. However, this experiment provides information on the destructive effect of chemical and microbial corrosion of concrete floors in pig farms. A new effective method is proposed to reduce the corrosive effect of the pigsty environment on concrete through the use of an experimental dry mixture for disinfection.

The direction of further research is the development of disinfectants for concrete in livestock farms with the prospect of forming a protective film.

\section{Conclusions}

1. The presence of microbial corrosion in the pigsty environment has been experimentally proven due to non-aggressive ones: $S$. aureus, E. coli, S. enteritidis, $S$. Choleraesuis, $C$. Perfringen and aggressive to concrete: bacteria $-A$. Thiooxidans and micromycetes - Cladosporium, Fusariums, Aspergillus. The fact of the negative influence of the applied disinfectants on the concrete structure was also established.

2. The studies have shown that the experimental dry mixture for disinfection exhibits antimicrobial properties to varying degrees to the strains of field isolates of bacteria and fungi isolated in a pig-breeding farm.

3. It has been found that when using the experimental dry mixture for disinfection in the research room of the pigsty, the relative humidity decreases by $38.5 \%$; ammonia content - by $46.2 \%$; hydrogen sulfide - by $57.8 \%$; microbial bodies - by $74.7 \%$, compared to the control room.

\section{Acknowledgement}

We would like to express our gratitude for the support in carrying out the research to the Chairman of the Board of OOO Brovafarma, D. Ven. D., Professor A. Berezovsky. The studies were carried out within the framework of R\&D (0121U109563) "Scientifically substantiated concept of prevention of epidemiologically significant bacterial diseases of animals on the basis of use of innovative technologies".

\section{References}

1. Qiu, L., Dong, S., Ashour, A., Han, B. (2020). Antimicrobial concrete for smart and durable infrastructures: A review. Construction and Building Materials, 260, 120456. doi: https://doi.org/10.1016/j.conbuildmat.2020.120456

2. Noeiaghaei, T., Mukherjee, A., Dhami, N., Chae, S.-R. (2017). Biogenic deterioration of concrete and its mitigation technologies. Construction and Building Materials, 149, 575-586. doi: https://doi.org/10.1016/j.conbuildmat.2017.05.144

3. Wang, J., Shen, J., Ye, D., Yan, X., Zhang, Y., Yang, W. et. al. (2020). Disinfection technology of hospital wastes and wastewater: Suggestions for disinfection strategy during coronavirus Disease 2019 (COVID-19) pandemic in China. Environmental Pollution, 262, 114665. doi: https://doi.org/10.1016/j.envpol.2020.114665 
4. Assaad Abdelmseeh, V., Jofriet, J., Hayward, G. (2008). Sulphate and sulphide corrosion in livestock buildings, Part I: Concrete deterioration. Biosystems Engineering, 99 (3), 372-381. doi: https://doi.org/10.1016/j.biosystemseng.2007.11.002

5. Shkromada, O., Paliy, A., Yurchenko, O., Khobot, N., Pikhtirova, A., Vysochin, I. et. al. (2020). Influence of fine additives and surfactants on the strength and permeability degree of concrete. EUREKA: Physics and Engineering, 2, 19-29. doi: https:// doi.org/10.21303/2461-4262.2020.001178

6. Johnson, T., Brineman, R., Schultze, C., Barkovskii, A. L. (2020). Efficient removal of bacteria from aqueous media with kaolinite and diatomaceous earth products. Journal of Applied Microbiology, 129 (3), 466-473. doi: https://doi.org/10.1111/jam.14642

7. Pereira, M. O., Vieira, M. J., Melo, L. F. (2002). The Role of Kaolin Particles in the Performance of a Carbamate-Based Biocide for Water Bacterial Control. Water Environment Research, 74 (3), 235-241. doi: https://doi.org/10.2175/106143002x139956

8. Douglas Hooton, R. (2019). Future directions for design, specification, testing, and construction of durable concrete structures. Cement and Concrete Research, 124, 105827. doi: https://doi.org/10.1016/j.cemconres.2019.105827

9. Shkromada, O., Paliy, A., Nechyporenko, O., Naumenko, O., Nechyporenko, V., Burlaka, O. et. al. (2019). Improvement of functional performance of concrete in livestock buildings through the use of complex admixtures. Eastern-European Journal of Enterprise Technologies, 5 (6 (101)), 14-23. doi: https://doi.org/10.15587/1729-4061.2019.179177

10. Maraveas, C. (2020). Durability Issues and Corrosion of Structural Materials and Systems in Farm Environment. Applied Sciences, 10 (3), 990. doi: https://doi.org/10.3390/app10030990

11. Veras, H. N. H., Rodrigues, F. F. G., Botelho, M. A., Menezes, I. R. A., Coutinho, H. D. M., da Costa, J. G. M. (2014). Antimicrobial Effect of Lippia sidoides and Thymol on Enterococcus faecalis Biofilm of the Bacterium Isolated from Root Canals. The Scientific World Journal, 2014, 1-5. doi: https://doi.org/10.1155/2014/471580

12. Pilotto, F., Rodrigues, L., Santos, L., Klein, W., Colussi, F., Nascimento, V. (2007). Antibacterial efficacy of commercial disinfectants on dirt floor used in poultry breeder houses. Revista Brasileira de Ciência Avícola, 9 (2), 127-131. doi: https://doi.org/10.1590/ s1516-635x2007000200009

13. Di Gregorio, M. C., Neeff, D. V. de, Jager, A. V., Corassin, C. H., Carão, Á. C. de P., Albuquerque, R. de et. al. (2014). Mineral adsorbents for prevention of mycotoxins in animal feeds. Toxin Reviews, 33 (3), 125-135. doi: https://doi.org/10.3109/15569543.2014.905604

14. Hassan, Y. I., Lahaye, L., Gong, M. M., Peng, J., Gong, J., Liu, S. et. al. (2018). Innovative drugs, chemicals, and enzymes within the animal production chain. Veterinary Research, 49 (1). doi: https://doi.org/10.1186/s13567-018-0559-1

15. Čolović, R., Puvača, N., Cheli, F., Avantaggiato, G., Greco, D., Đuragić, O. et. al. (2019). Decontamination of MycotoxinContaminated Feedstuffs and Compound Feed. Toxins, 11 (11), 617. doi: https://doi.org/10.3390/toxins11110617

16. Benhalima, L., Amri, S., Bensouilah, M., Ouzrout, R. (2019). Antibacterial effect of copper sulfate against multi-drug resistant nosocomial pathogens isolated from clinical samples. Pakistan Journal of Medical Sciences, 35 (5). doi: https://doi.org/10.12669/ pjms.35.5.336

17. Zhao, T., Zhao, P., West, J. W., Bernard, J. K., Cross, H. G., Doyle, M. P. (2006). Inactivation of Enterohemorrhagic Escherichia coli in Rumen Content- or Feces-Contaminated Drinking Water for Cattle. Applied and Environmental Microbiology, 72 (5), 3268-3273. doi: https://doi.org/10.1128/aem.72.5.3268-3273.2006

18. Pokrovskiy, V. A. (2000). Temperature-programmed Desorption Mass Spectrometry. Journal of Thermal Analysis and Calorimetry, 62, 407-415. doi: https://doi.org/10.1023/A:1010177813557

19. Wasik, A. (2007). Electron Microscopy: Methods and Protocols, by J. Kuo, ed. Humana Press 2007. 608 pp. ISSN 1064-3745. Acta Biochimica Polonica, 54 (4), 887-888. Available at: https://ojs.ptbioch.edu.pl/index.php/abp/article/view/5078/4128

20. Ettenauer, J. D. (2010). Culture dependent and -independent identification of microorganisms on monuments. University of Vienna. doi: https://doi.org/10.25365/thesis.9752

21. Nieminen, S. M., Kärki, R., Auriola, S., Toivola, M., Laatsch, H., Laatikainen, R. et. al. (2002). Isolation and Identification of Aspergillus fumigatus Mycotoxins on Growth Medium and Some Building Materials. Applied and Environmental Microbiology, 68 (10), 4871-4875. doi: https://doi.org/10.1128/aem.68.10.4871-4875.2002

22. Balouiri, M., Sadiki, M., Ibnsouda, S. K. (2016). Methods for in vitro evaluating antimicrobial activity: A review. Journal of Pharmaceutical Analysis, 6 (2), 71-79. doi: https://doi.org/10.1016/j.jpha.2015.11.005

23. Bertron, A., Peyre Lavigne, M., Patapy, C., Erable, B. (2017). Biodeterioration of concrete in agricultural, agro-food and biogas plants: state of the art and challenges. RILEM Technical Letters, 2, 83-89. doi: https://doi.org/10.21809/rilemtechlett.2017.42

24. Hong, M., Jang, I., Son, Y., Yi, C., Park, W. (2021). Agricultural by-products and oyster shell as alternative nutrient sources for microbial sealing of early age cracks in mortar. AMB Express, 11 (1). doi: https://doi.org/10.1186/s13568-020-01166-5

25. Shkromada, O., Ivchenko, V., Chivanov, V., Tsyhanenko, L., Tsyhanenko, H., Moskalenko, V. et. al. (2021). Defining patterns in the influence exerted by the interelated biochemical corrosion on concrete building structures under the conditions of a chemical enterprise. Eastern-European Journal of Enterprise Technologies, 2 (6 (110)), 52-60. doi: https://doi.org/10.15587/ 1729-4061.2021.226587

26. Strokova, V., Nelyubova, V., Rykunova, M., Dukhanina, U. (2019). Strength and structure of cement stone exposed to domestic chicken coop. Journal of Physics: Conference Series, 1145, 012015. doi: https://doi.org/10.1088/1742-6596/1145/1/012015

27. Huber, B., Hilbig, H., Drewes, J. E., Müller, E. (2017). Evaluation of concrete corrosion after short- and long-term exposure to chemically and microbially generated sulfuric acid. Cement and Concrete Research, 94, 36-48. doi: https://doi.org/10.1016/ j.cemconres.2017.01.005 